\title{
Light supports cell-integrity and growth rates of taxonomically diverse coastal photoheterotrophs
}

Nestor Arandia-Gorostidi ${ }^{1,2}$, José M. González ${ }^{3}$, Tamara Huete-Stauffer ${ }^{1,4}$, Mohd I. Ansari ${ }^{4}$, Xosé Anxelu G. Morán ${ }^{4}$, Laura Alonso-Sáez ${ }^{1,5}$

${ }^{1}$ Instituto Español de Oceanografía, Centro Oceanográfico de Gijón/Xixón, Gijón/Xixón, Asturias (Spain)

${ }^{2}$ Department of Earth System Science, Stanford University, Stanford, CA, USA

${ }^{3}$ Department of Microbiology, University of La Laguna, La Laguna, Spain

${ }^{4}$ King Abdullah University of Science and Technology (KAUST), Red Sea Research Center, Biological and Environmental Sciences and Engineering Division, Thuwal, Saudi Arabia

${ }^{5} \mathrm{AZTI}$, Marine Research, Basque Research and Technology Alliance (BRTA). Txatxarramendi ugartea z/g, 48395 Sukarrieta - Bizkaia

Corresponding authors:

Nestor Arandia-Gorostidi

Stanford University

Department of Earth System Science Green Earth Sciences Building

367 Panama St., Room 129

Stanford, CA 94305-4216

Email: n.arandia86@gmail.com
Laura Alonso-Sáez

AZTI

Marine Research

Basque Research and Technology Alliance

(BRTA)

Txatxarramendi ugartea z/g Sukarrieta, Bizkaia 48395 Spain

Email: lalonso@azti.es

Running title: Light promotes environmental bacterial growth

This article has been accepted for publication and undergone full peer review but has not been through the copyediting, typesetting, pagination and proofreading process which may lead to differences between this version and the Version of Record. Please cite this article as doi: $10.1111 / 1462-2920.15158$ 


\section{Significance Statement}

Proteorhodopsins are light-driven proton pumps broadly distributed among many different groups of marine heterotrophic bacteria. Despite their widespread distribution, the metabolic advantages of harboring proteorhodopsin have only been observed in a few bacterial isolates and the impact of light-harvesting on environmental photoheterotrophs is still largely unknown. In this work, we investigated the effect of light radiation on the growth rates and cell integrity of different photoheterotrophic groups in temperate waters over nearly a year. We found that particularly during spring, light enhanced the metabolism of numerous marine bacterial taxa including Polaribacter and Tenacibaculum, as well as some Alteromonadales and Pelagibacterales, all of which are known to contain proteorhodopsins based on genome sequencing. This finding shows evidence of light-induced increases in growth and cell integrity of photoheterotrophs in environmental waters during a post-bloom scenario, representing an important step forward in our understanding of the impact of light on the metabolism of natural microbial communities. 


\section{Summary}

Despite the widespread distribution of proteorhodopsin (PR)-containing bacteria in the oceans, the use of light-derived energy to promote bacterial growth has only been shown in a few bacterial isolates, and there is a paucity of data describing the metabolic effects of light on environmental photoheterotrophic taxa. Here, we assessed the effects of light on the taxonomic composition, cell integrity and growth responses of microbial communities in monthly incubations between spring and autumn under different environmental conditions. The photoheterotrophs expressing PR in situ were dominated by Pelagibacterales and SAR116 in July and November, while members of Euryarchaeota, Gammaproteobacteria and Bacteroidetes dominated the PR expression in spring. Cell-membrane integrity decreased under dark conditions throughout most of the assessment, with maximal effects in summer, under low-nutrient conditions. A positive effect of light on growth was observed in one incubation (out of nine), coinciding with a declining phytoplankton bloom. Light-enhanced growth was found in Gammaproteobacteria (Alteromonadales) and Bacteroidetes (Polaribacter and Tenacibaculum). Unexpectedly, some Pelagibacterales also exhibited higher growth rates under light conditions. We propose that the energy harvested by PRs helps to maintain cell viability in dominant coastal photoheterotrophic oligotrophs while promoting growth of some widespread taxa benefiting from the decline of phytoplankton blooms. 


\section{Introduction}

Photoheterotrophy is the ability of some heterotrophic prokaryotes to transform solar energy into an electrochemical gradient while using organic molecules as a carbon and energy source. Photoheterotrophic microbes are widespread in marine environments (Rusch et al., 2007; Campbell et al., 2008), distributed among major phyla (de la Torre et al., 2003; Olson et al., 2018), and present in two groups: (i) aerobic anoxygenic phototrophic (AAP) bacteria (Tsuneo Shiba, 1979), which contain bacteriochlorophyll $a$ (Bchl a); and (ii) PR-containing prokaryotes including bacteria and archaea (Béjà et al., 2000; de la Torre et al., 2003; Frigaard et al., 2006), which use PR proteins to generate energy. AAPs usually represent less than $10 \%$ of the total bacterial cells in marine waters, though this value is occasionally exceeded in estuarine waters (Schwalbach and Fuhrman, 2005). In contrast, PR-containing microbes are widely distributed in the oceans, comprising more than $50 \%$ of total microbial abundance in some oceanic regions such as the Sargasso Sea (Venter et al., 2004; Campbell et al., 2008) and up to 90\% in coastal waters (Moran and Miller, 2007; Finkel et al., 2013). PR genes have been detected in the three domains of life and have a widespread taxonomic distribution (Sharma et al., 2006), including some of the most abundant clades in the ocean: SAR11 (Giovannoni et al., 2005); SAR86 (Béjà et al., 2000); and different members of Flavobacteriia (Gómez-Consarnau et al., 2007; González et al., 2008; Yoshizawa et al., 2012).

Despite the great abundance of photoheterotrophy genes in the ocean, the metabolic advantages of harboring light-harvesting mechanisms remain unclear. In the case of AAPs, light-promoted growth has been observed in cultures of Rhodobacteraceae (Biebl and Wagner-Döbler, 2006), Erythrobacter (Yurkov and van Gemerden, 1993), and also in natural assemblages (Ferrera et al., 2017). It has been observed that PR-containing microbes can use light radiation to generate a transmembrane proton gradient, which can be used to synthesize ATP (Martínez et al., 2007) and/or to facilitate uptake of essential nutrients (Gómez- 
Consarnau et al., 2016). Different works have shown that this additional energy can be used by the cells to enhance survival, as observed for a Vibrio (strain AND4) and Candidatus Pelagibacter ubique (strain HTCC1062) isolates under low availability of carbon (Gómez-Consarnau et al., 2010; Steindler et al., 2011). It has also been shown that light can support the growth of a handful of strains predominately affiliated with Flavobacteria (e.g., Dokdonia strain MED134; Gómez-Consarnau et al., 2007, Psychroflexus torquis ATCC 700755; Feng et al., 2013, Nonlabens marinus S1-08; Yoshizawa et al., 2014, Polaribacter MED152; Fernández-Gómez, 2012), in addition to the Gammaproteobacterium HIMB30 (Michelou, 2014). The mechanism behind the light-enhanced growth in these strains remains unclear, but it has shown to be related to the uptake of the vitamin $\mathrm{B}_{1}$ in auxotrophic Dokdonia isolates, promoted by the PR-generated proton motive force (PMF; Gómez-Consarnau et al., 2016). However, the fact that light-enhanced growth was not observed in other widespread PR-containing microbial isolates, such as the Cand. P. ubique strain HTCC1062 (Giovannoni et al., 2005; Steindler et al., 2011) or the SAR92 strain HTCC2207 (Stingl et al., 2007), suggests that the energy obtained by PR is predominately used in metabolic processes which do not result in increased growth. Furthermore, the lack of experimental evidence of the effect of light on the growth of photoheterotrophs in environmental waters has led to the view that PR activity may not have any relevant impact on the biomass of natural communities of heterotrophic bacteria.

Analyzing the metabolic effects of light on widespread photoheterotrophic taxa under environmental conditions is, however, challenging. Indirect effects of light, such as the increase in photosynthate availability in the incubations is the most obvious confounding factor in experiments conducted with entire microbial communities, hindering the real effect of light on photoheterotrophic bacterial biomass and activity. Seasonally changing environmental conditions, particularly resource availability, may also have an important impact on the response of dominant photoheterotrophic taxa, but has been rarely assessed in 
studies on photoheterotrophs in natural waters. Here, we carried out experimental incubations of natural bacterial communities during a nearly complete annual cycle from a temperate marine site in NE Atlantic coastal waters. After removing most of the autotrophic cells and incubating the remaining microbes under light and dark conditions, we: i) identified active photoheterotrophs in this coastal system; and ii) determined the potential effect of photoheterotrophy on the growth and physiological integrity of widespread marine bacterial taxa. 


\section{Results}

Environmental setting and identification of active photoheterotrophic bacteria in situ by metatranscriptomics

Seawater was sampled monthly between April and December of 2012 at the mid-shelf station of the Southern Bay of Biscay (E2-Gijón/Xixón), which ranges from oligotrophic to mesotrophic conditions. Dissolved inorganic nitrogen concentration showed a maximum in March (4.95 $\left.\mu \mathrm{mol} \mathrm{Kg}^{-1}\right)$ and decreased thereafter to a minimum in June $\left(0.51 \mu \mathrm{mol} \mathrm{kg}{ }^{-1}\right.$, Fig. S1). Maximum values of in situ chlorophyll $a$ (Chl a) concentration were found at the beginning of May $\left(1.41 \mu \mathrm{g} \mathrm{L}^{-1}\right)$ and December (1.80 $\mu \mathrm{g} \mathrm{L}{ }^{-1}$, Fig. S1), and the minimum value was found in July $(0.39 \mu \mathrm{g} \mathrm{L}-1)$. Shortly after the peak of the beginning of May, Chl $a$ dropped abruptly to $0.58 \mu \mathrm{g} \mathrm{L}^{-1}$ three weeks later, indicative of typical post-bloom conditions in late spring at the E2-Gijón/Xixón station. Cell-specific heterotrophic bacterial production (sBP) was also analyzed as a proxy of dissolved organic matter (DOM) availability. Maximum sBP was found in May (7.9

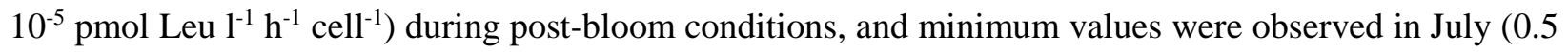
$10^{-5}$ pmol Leu $^{-1} \mathrm{~h}^{-1}$ cell $\left.^{-1}\right)$.

A metatranscriptomic analysis conducted on samples collected in April, May, July and November during the period of study was used to identify the most active photoheterotrophs in situ. Transcripts of pufM (a marker gene for aerobic anoxygenic photosynthesis) were only found in April and July and their relative abundance in the metatranscriptomes was very low ( $<0.001 \%$ of transcripts); thus, these transcripts were not further analyzed. By contrast, PR transcripts were highly expressed throughout the year (with up to 2.7\% of total transcripts in July, Fig. 1A). The composition of the microbial communities expressing PRs showed important changes at different times of the year. For example, Pelagibacteraceae contributed a 
relatively high percentage of PR transcripts (up to 50\%) in July and November, but contributed only 10\% of transcripts during spring (Fig. 1B). While PR transcripts affiliated with Cand. P. ubique HTCC1062 and HIMB058 were detected in July and November, HIMB058 dominated Pelagibacteraceae PR expression in spring (Fig. S2). SAR116 (Alphaproteobacteria) PR transcripts were also abundant in summer, representing 26\% of total PR transcripts in July. In April, a clear dominance of Gammaproteobacteria (46\% of PR transcripts) was observed, while in May, Euryarchaeota dominated PR expression (44\%). Most of the PR-containing Gammaproteobacteria were affiliated with SAR86 and SAR92, while Thioglobus were also significant contributors in April (Fig. 1B, Fig. S2). PR expression by members of the Bacteroidetes phylum (primarily from the family Flavobacteriaceae) was also noticeable, with maximum expression in spring (17\% and 16\% of PR transcripts in April and May, respectively).

Effects of light on prokaryotic cell membrane integrity and specific growth rates across a gradient of seasonally-changing environmental conditions

Seawater samples were prefiltered (using $0.8 \mu \mathrm{m}$ pore-size filters to remove potential bacterial predators and most phytoplankton cells) and incubated either under saturating (435 $\pm 5 \mu$ mol photons $\left.\mathrm{m}^{-2} \mathrm{~s}^{-1}\right)$ photosynthetically active radiation (PAR) light irradiance ("light treatment”) or completely dark conditions (“dark treatment”) in triplicate bottles. We found that the pre-filtration treatment removed virtually all heterotrophic nanoflagellates and Chl $a$, including most cyanobacterial cells (Table 1), while reducing only $8.4 \%$ ( $\pm 15.5 \% \mathrm{SD})$ of heterotrophic bacteria on average. In particular, we removed $85.2 \%$ of picoeukaryotes and $\mathbf{8 7 . 7 \%}$ of cyanobacteria (comprised of mostly Synechococcus since Prochlorococcus was absent from March until August, typical of this coastal system; Calvo-Díaz et al., 2008). In order to control the potential impact of regrowth of phototrophic organisms under light conditions during the 
incubations, the dynamics of cyanobacteria and autotrophic eukaryotes were analyzed by flow cytometry (Fig. S3 and S4). In April, the abundance of cyanobacteria remained low during the incubations (less than 1000 cells $\mathrm{ml}^{-1}$ ), while the abundance of picoeukaryotes increased after 1 day of incubation. In May, we did not observe any growth of cyanobacteria or autotrophic eukaryotes during the entire incubations. In summer, Synechococcus grew after the first day of incubation under light conditions, particularly in July and September, when they reached up to $55.810^{3}$ cells $\mathrm{ml}^{-1}$. Phototrophic picoeukaryotes also showed slight growth in June and July under light conditions. In autumn, no significant growth of Synechococcus was found under light conditions, but Prochlorococcus abundance increased in the dark incubations, particularly in October. Notably, the increase in Prochlorococcus abundance under dark conditions took place only during the first day of incubation and thereafter, their abundance remained constant until the end of the incubations. The same effect was found for Synechococcus in December, when they grew during the first day in the dark, but not under light conditions.

The flow cytometric analysis of cell-membrane integrity (i.e., cells with intact or damaged membranes) showed that the contribution of Live cells in the light treatment was significantly higher than in the dark treatment for all the analyzed months (paired t-test, $\mathrm{p}$-value $=0.001, \mathrm{n}=9$, Fig. $2 \mathrm{~A}$ ). On average, the contribution of Live cells to total microbial abundance was $89.8 \% \pm 3.7 \%$ in the light treatment, dropping to a mean of $77.7 \% \pm 8.5 \%$ in the dark, although it varied temporally. Such a difference was already noticeable during the first day of incubation (Fig. S5), when the average of Live cells was $89.7 \% \pm 4.9 \%$ and $76.8 \% \pm 9.1 \%$ in light and dark treatments, respectively. The largest difference in the percentage of Live cells occurred in summer (on average in August, $87.8 \%$ and $65.1 \%$ for light and dark incubations, respectively). In autumn, the difference was minor (92.9\% vs. $90.0 \%$ in November and $93.7 \%$ vs. $89.4 \%$ in December), although still significant (t-test, $\mathrm{p}$-value $<0.001$, $\mathrm{n}=6$ for both months). 
In the same light-controlled incubations, maximum specific growth rates of the bulk microbial community were observed in spring (Fig. 2B), with a peak in May $\left(1.59 \pm 0.03 \mathrm{~d}^{-1}\right)$, while relatively low values were measured from July through December (minimum in October, $0.17 \pm 0.02 \mathrm{~d}^{-1}$ ). In May and June, we found significant differences in the growth rates between light and dark treatments (ANOVA, p-value <0.001), with up to 2 times higher bacterial growth rates in the light treatment in May. Although a significant increase in the growth rate of heterotrophic bacteria under light conditions was also observed in July, we cannot exclude the possibility that this was related to the concomitant growth of cyanobacteria in those incubations. For the rest of the year, growth rates were not significantly different in light and dark treatments except for November, when growth rates were slightly higher in the dark (t-test, $\mathrm{p}$-value $=0.006, \mathrm{n}=6$ ). Regarding the maximum microbial abundance reached during the incubations or carrying capacity (Huete-Stauffer et al., 2015), the highest differences between the light and dark treatment were also found in spring and early summer (Fig. S6).

\section{Effects of light on microbial community composition}

We analyzed the variability in bacterial community composition monthly at in situ conditions and during some of the incubations under light and dark treatments (June, July, August and December, Fig. 3 and Fig. S7). Under in situ conditions, microbial communities were clearly dominated by members of Flavobacteriaceae (such as Tenacibaculum) or Rhodobacteraceae (Roseobacter clade) in April and May, and by SAR11 from June to December. The bacterial community composition changed substantially over the course of the incubations (Fig. 3B, Fig. S7). However, differences in the overall community composition between the light and dark treatment at the end of the incubation were not large (Fig. 3B, Fig. S7). The lack of replicates and the challenges associated with the analysis of relative abundance data precludes drawing 
clear conclusions from the comparison of light and dark incubations based on sequencing data. However, this analysis allowed us to identify taxa from widespread taxonomic groups present in situ and in the seawater incubations known to harbor PR but with little or no experimental evidence of their metabolic response to light (e.g., Polaribacter, Tenacibaculum, Alteromonadales), which were subsequently targeted with specific probes (see results below).

At the beginning and the end of the incubations in May and June, when stronger effects of light on bacterial growth rates were observed (Fig. 2), we also analyzed full-length bacterial 16S rRNA genes by cloning and sequencing to obtain a finer taxonomic resolution (Fig. S8, S9). Although we found few clones affiliated with Gammaproteobacteria at the beginning (T0) of the May incubation, 30\% of the total clones were affiliated with Alteromonadales by the end of the incubation, some of which (15\% of Alteromonadales clones) were closely related (> 99\% similarity) to two strains known to harbor the PR gene (Alteromonas LOR and Alteromonas MB-3u-76; Kopel et al., 2014; Tully et al., 2017; Fig. S8). In the June experiment, Gammaproteobacteria were clearly dominated by the SAR86 clade both at the initial and final timepoints of the incubation. In the phylum Bacteroidetes, clones related to the PR-containing flavobacterium MS0242A (Formosa and Polaribacter) were found at the end of the light incubations in May and June. Regarding Rhodobacteraceae, clones related to taxa known to contain Bchl $a$ were found: mainly Loktanella, but also Thalassobium or Planktomarina temperata (Fig. S9). In the case of Pelagibacterales, at the initial timepoint of the incubations in May most clones were related to the Group II (Fig. S9), while at the end of the incubations no clones were detected due to the low relative abundance of SAR11 in comparison with other groups ( $<1 \%)$. In June, we found clones affiliated with the SAR11 Group I at the beginning and the end of light incubations.

Effect of light on the growth rates of specific bacterial taxa 
The effect of light on the growth of Gammaproteobacteria, Bacteroidetes, Rhodobacteraceae and SAR11 was assessed monthly from April to December by Catalyzed Reporter Deposition Fluorescence In Situ Hybridization (CARD-FISH; Fig. 4A) in incubations that lasted between 3 and 5 days. A significant effect of light on the specific growth rates of SAR11 was found in May and June (ANCOVA, p-value <0.001). The largest difference was found in May, when phototrophic microorganisms were completely absent from the filtered incubations and SAR11 showed a specific growth rate of $1.45 \mathrm{~d}^{-1}$ under light conditions but no growth in the dark (Fig. 4A). Differences in growth rates between the light and dark treatments for Gammaproteobacteria and Bacteroidetes were also most conspicuous in May, with significantly higher specific growth rates under light exposure (ANCOVA, p-value<0.001) representing 1.7 and 1.8-fold increases, respectively, compared to the dark incubations. In June, the increase in specific growth rate for these groups was less pronounced but still significant for Bacteroidetes (ANCOVA, p-value<0.001).

At a more specific taxonomic level, the growth response to light exposure in Tenacibaculum, Polaribacter and Alteromonadales was analyzed in May (Fig. 4B). These three bacterial groups contributed up to 14\%, $4 \%$ and $2 \%$ of sequence reads at the initial timepoint in May, respectively (Fig. 3A). Tenacibaculum showed three times higher growth rates in the light compared to the dark treatment $\left(1.67 \mathrm{~d}^{-1}\right.$ and $0.56 \mathrm{~d}^{-1}$ in light and dark, respectively), while Polaribacter showed 1.6 times higher growth $\left(1.90 \mathrm{~d}^{-1}\right.$ and $1.10 \mathrm{~d}^{-1}$ in light and dark). In the case of Alteromonadales, the increase in growth was even more noticeable (up to 15-fold, $2.38 \mathrm{~d}^{-1}$ in the light vs. $0.15 \mathrm{~d}^{-1}$ in the dark). In general, the effects of light on the growth of Rhodobacteraceae were less pronounced, although rates were significantly higher in the light compared to the dark during the September incubation (ANCOVA, p-value $=0.003$ ). On the contrary, occasional higher growth rates in the dark treatment than in the light were also observed, particularly in April for Bacteroidetes and Gammaproteobacteria. 
TonB receptors in bacterial genomes and their in situ expression

Since the expression of TonB receptors has been shown to be related to the light-enhanced growth of some PR-containing flavobacteria (Gómez-Consarnau et al., 2016), we addressed the potential relevance of this process in our samples. First, we carried out an analysis of TonB receptors in a comprehensive database of marine bacterial genomes (MAR database; Klemetsen et al., 2018), searching for three main types of TonB transporters: TonB receptors involved in the transport of vitamin $\mathrm{B}_{1}$; TonB involved in the transport of iron (haem groups); and the gene tandem susC (TonB transporter)-susD (substrate binding and delivery to susC), involved in polymer degradation and transport of degradation products. We found that TonB transporters were widely distributed among members of Gammaproteobacteria and Flavobacteriia, while they were absent from Pelagibacter. In particular, members of Alteromonadales and Flavobacteriia, including PRcontaining genera for which a light-enhanced growth has been shown in this or previous studies (Dokdonia, Tenacibaculum and Polaribacter) had a high number of TonB transporters in their genomes (Fig. 5B). Predicted susC-susD genes were dominant in Flavobacteriia ( 30\% of total TonB transporter genes), although we also found some receptors of this type in several genomes of Alteromonas (Fig. 5B). A copy of the TonB receptor specific for transporting vitamin $\mathrm{B}_{1}$ was predicted in all 72 Flavobacteriia and all 27 Alteromonas genomes (except one) in the MAR database, including those closely related to the taxa found in our incubations (e.g., Polaribacter sp. Hel1_33_78 or Alteromonas sp. MB-3u-76; results not shown). Our search also retrieved eight Bacteroidetes genomes not affiliated with Flavobacteriia: Caldithrix abyssi (Calditrichaeota) and a Sulfurovum genome (Epsilonproteobacteria). The phylogenetic reconstruction was congruent with the taxonomy, although the position of Sulfurovum suggests a lateral gene transfer event (Fig. S10). 
Second, we analyzed the in situ expression of these transporters in the metatranscriptomes collected at the E2-Gijón/Xixón station to assess their transcriptional activity across the seasonal gradient. We found that the TonB receptor genes analyzed were highly expressed, at the same level as PRs (ranging from 0.5 to 1.3 $\%$ of all transcripts). The expression was maximal in spring and declined in summer and autumn (Fig. 5A). On average, the expression of TonB receptors specific for transporting vitamin $\mathrm{B}_{1}$ and haem receptors was lower ( $0.01 \%$ of all transcripts), but the maximum expression of vitamin $\mathrm{B}_{1}$ receptor genes were found in May. 


\section{Discussion}

The high diversity of PR genes found in the surface ocean represented one of the most outstanding discoveries from the sequencing of the first marine metagenomes (Venter et al., 2004). Later studies have supported the view that PR-based photoheterotrophy is widespread in dominant microbial taxa in the marine photic layer (de la Torre et al., 2003; Campbell et al., 2008). Given the large number of planktonic heterotrophic prokaryotes containing this light-harvesting mechanism, their contribution to the ocean's energy flux is potentially large. However, its quantification remains challenging (DeLong and Béjà, 2010), and in general, our understanding of the metabolic and biogeochemical consequences of harboring lightharvesting systems has grown at a much slower pace compared to our understanding of their genetic diversity. At the community level, there is evidence for light enhancing major metabolic processes such as heterotrophic bacterial production (Morán et al., 2001). However, results have not always been consistent (Ruiz-González et al., 2012) and dark conditions are still widely used for measuring biomass production rates of marine heterotrophic bacteria and archaea (Lemée et al., 2002; Tada et al., 2011), thereby neglecting the potential impact of photoheterotrophy.

Most of the studies addressing the metabolic advantages of photoheterotrophy have almost exclusively focused on bacterial cultures. The lack of experimental evidence of environmental photoheterotrophic activity is mostly due to the difficulty in differentiating a direct effect of light on the metabolism of photoheterotrophs from an indirect effect, e.g., mediated by the carbon supply by phytoplanktonic organisms. Here, we used a pre-filtration step, which was generally very effective in reducing the concentration of Chl $a$ and the abundance of photosynthetic organisms in the incubations, except in autumn when cyanobacterial communities were largely comprised of the small-sized Prochlorococcus. Yet, in some months we observed substantial regrowth of Synechococcus (particularly in July and August) or 
picoeukaryotes (in April and November) under light conditions in the incubations. Interestingly, the opposite result was found in the case of Prochlorococcus from October to December, as their abundance increased under dark conditions during the first day of incubation. Prochlorococcus have a tightly synchronized cell cycle regulated by the photoperiod, dividing at the beginning of the dark period (Vaulot et al., 1995; Jacquet et al., 2001; Biller et al., 2018). Thus, we hypothesize that Prochlorococcus cells went through a first round of division after placing them under dark conditions, but their growth ceased afterwards. The decrease in the abundance of Prochlorococcus cells under light conditions could be due to a photoinhibition effect by PAR light, as also found in previous studies (Sommaruga et al., 2005; MellaFlores et al., 2012). Higher specific growth rates of heterotrophic bacteria in the dark incubations was also occasionally detected, which could also be related to photoinhibition (Ruiz-González et al., 2012). A negative effect of PAR radiation on the uptake of organic compounds (amino acids) in abundant groups such as SAR11 has been experimentally tested in previous studies (Alonso-Sáez et al., 2006; Ruiz-González et al., 2012). We infer that a similar effect may have happened in April, limiting the growth rates of some bacteria under light conditions. In any case, it is also remarkable that the regrowth of photosynthetic organisms in the incubations during April, summer and autumn did not substantially impact the growth rates of bacterial heterotrophic communities. More importantly, in May, when we observed the highest increase of bacterial growth rates under light conditions, cyanobacteria were not detected in the incubations (either by flow cytometry or high-throughput sequencing) and autotrophic eukaryote abundances and Chl $a$ concentrations were negligible. The absence of autotrophic cells implies that the results obtained in that month were independent of the potential effects of photosynthetic organisms.

Although the growth rates and overall taxonomic composition were similar in both dark and light incubations for most of the analyzed months, an increase in the abundance of bacteria with intact cell 
membranes was generally found under light. The mean contribution of Live cells in the experiments conducted in the light ranged from $82 \%$ to $94 \%$, similar to the variability found in natural communities from the same site (Morán and Calvo-Díaz, 2009). In the dark, however, this value dropped below 80\% in half of the monthly incubations, a value never found at our study site under natural conditions (Morán and Calvo-Díaz, 2009; Huete-Stauffer et al., 2015). While we cannot rule out that the growth of photosynthetic organisms in the incubations may have impacted this result, the increase of Live cells in the light treatment was also clearly observed in May, when the potential impact of photoautotrophs was negligible. Furthermore, the marked decrease of Live cells under dark conditions (generally within one day) took place before the regrowth of photosynthetic organisms (Fig. S3), supporting the view that light was sustaining cell-membrane integrity in a substantial fraction of bacterial cells. We hypothesize that the energy provided by PR may be crucial for maintaining essential metabolic processes in some marine bacteria, avoiding cell death. In support of our results, a previous study on the photoheterotrophic isolate Vibrio AND4 showed a positive effect of light on cell survival under oligotrophic conditions (Gómez-Consarnau et al., 2010), and light has been found to promote the maintenance of ATP content and substrate transport rates in starved SAR11 cells (Steindler et al., 2011). Remarkably, we found that the maximum effect of light on cell membrane integrity was found in incubations with seawater collected in summer, when oligotrophic conditions prevail at our study site (Calvo-Díaz and Morán, 2006; Huete-Stauffer et al., 2015) and SAR11 was dominant. However, further work is needed to confirm this pattern, as we could not avoid the confounding factor of cyanobacteria re-growth in summer incubations.

The specific growth rate is a key parameter to characterize the ecological success of bacterial taxa (Kirchman, 2016). Thus, the ability to use light to promote growth may represent an important competitive advantage for some photoheterotrophs. However, in previous studies, light has been found to positively 
impact the growth rates of only a few photoheterotrophic bacterial isolates, mainly affiliated with Flavobacteriia (Gómez-Consarnau et al., 2007; Yoshizawa et al., 2014). Here, we found that during the decline of the spring phytoplankton bloom, light promoted the growth of different taxa, including two ecologically relevant flavobacteria: Polaribacter and Tenacibaculum. These two taxa are typically associated with phytoplankton (Klindworth et al., 2014; Xing et al., 2015; Pearman et al., 2016) and contain members that harbor PR genes in their genomes (González et al., 2008; Yoshizawa et al., 2012; Pearman et al., 2016). Yet, evidence showing that light can promote their growth is scarce, i.e., only observed for one Polaribacter strain (MED152; Gómez-Consarnau et al., 2007), with no experimental evidence reported for Tenacibaculum. The fact that Polaribacter and Tenacibaculum grew better under light conditions at the time of the highest seasonal DOM bioavailability (according to the bacterial production measurements; Fig. S1) contrasts with previous isolate-based studies in which light-enhanced growth was found mostly under low or intermediate DOM concentrations (Gómez-Consarnau et al., 2007; Michelou et al., 2007; Yoshizawa et al., 2014). Thus, our results provide new perspectives to understand the environmental context where light can promote the growth of photoheterotrophic bacteria in coastal waters.

Members of another environmentally relevant taxon in marine waters, the Alteromonadales order, also grew in response to light. A role of photoheterotrophy for this model copiotroph has not been previously considered, as they are dominant members of the aphotic oceanic realm (Salazar et al., 2016) and typically outgrow other heterotrophic taxa in dark bottle incubations (Alonso-Sáez et al., 2010). Indeed, PR genes are not widely distributed among Alteromonadales; from a total of 123 genomes of Alteromonadaceae in the MAR database, we found PR-coding genes in only four strains (Alteromonas sp. LOR 57, MB-3u-76, MED668 and LTR 27) which have been described very recently (Kopel et al., 2014; Tully et al., 2017). Interestingly, in the light incubations in May, some of the clones affiliated with Alteromonas had $>99 \%$ 
similarity with some of these PR-containing strains (i.e., Alteromonas LOR, LTR, MB-3u76), which was consistent with their growth-response under light conditions. Additionally, some clones were closely related to Glaciecola, in which PR-coding genes have been also observed (Qin et al., 2012; Boeuf et al., 2016). Although less abundant than Alteromonas, Glaciecola was also present in our incubations and can be hybridized by the ALT1413 probe. Thus, we cannot discard the possibility that some of the ALT1413hybridized cells with light-enhanced growth were affiliated with the latter genus.

Another surprising observation from our results was the higher growth rates of some SAR11 members in May under light conditions. Previous studies have shown that light does not promote the growth of the SAR11 model strain Cand. P. ubique HTCC1062 (Giovannoni et al., 2005), although a positive effect on their survival has been observed (Steindler et al., 2011). Cand. P. ubique HTCC1062 is a representative of the SAR11 Group I, which dominated the Pelagibacterales sequence reads in eight out of nine months of our analysis (Arandia-Gorostidi et al., 2017). However, in the samples taken in May, a clear shift in their composition was found, with SAR11 Group II becoming dominant (Arandia-Gorostidi et al., 2017). While SAR11 Group I is mostly found under oligotrophic conditions, relative contribution of Group II usually peaks in Spring (Giovannoni, 2017), in agreement with the observations in our study. Even if the specific growth rates of Pelagibacterales members are generally low (Kirchman, 2016), occasional high activity of SAR11 cells has been also reported (Malmstrom et al. 2004). Similarly, the SAR11 growth rates we measured in May were high, comparable to members of groups such as Rhodobacteraceae and Gammaproteobacteria (Arandia-Gorostidi et al., 2017), but as we show in this work, only under light conditions. Thus, our results suggest that some members of SAR11 increase their metabolism under light conditions, most likely related with their photoheterotrophic ability. 
In general, the fact that light promotes the growth of only a fraction of PR-bearing isolates is intriguing. One recent study showed that some Dokdonia isolates auxotrophic for vitamin $\mathrm{B}_{1}$ (DSW-1 ${ }^{\mathrm{T}}$ and MED134) actively expressed a predicted TonB receptor specific for the transport of vitamin $\mathrm{B}_{1}$ under light conditions. This result indicated that the proton motive force generated by PR under light conditions facilitated the incorporation of this essential growth factor, likely explaining their higher growth rates in the light (GómezConsarnau et al., 2016). Besides vitamins, TonB membrane transporters are used to take up a wide range of compounds, including iron, carbohydrates and small peptides (Tang et al., 2012). Additionally, uptake rates of other compounds (such as taurine) have been observed to be more active in the presence of light (Steindler et al., 2011), suggesting that light-enhanced metabolism can indeed be related to an increased ability to incorporate compounds by PR-containing bacteria. This high abundance of TonB transporter transcripts detected under the phytoplankton post-bloom conditions in May (with a maximum relative abundance of vitamin $B_{1}$ receptors), may suggest that taxa harboring PRs can take advantage of the proton motive force generated from light to incorporate essential compounds such as vitamin $\mathrm{B}_{1}$.

In summary, PR expression is an adaptation by some members of the bacterioplankton community to take advantage of light energy. Here, we detected that in the absence of potential confounding effects of photosynthetic organisms, the use of light promoted the growth of taxonomically diverse bacterial taxa, but only under very specific environmental conditions (i.e., a post-bloom scenario). This would reconcile our results with those of previous studies where light did not impact the taxonomic composition of bacterial communities in seawater incubations (Schwalbach et al., 2005). The photoheterotrophs showing lightenhanced growth were affiliated with environmentally relevant taxa (including Tenacibaculum, Polaribacter and Alteromonadales), which may have a key role in carbon processing under high DOM availability conditions. Some members of Pelagibacterales may also take advantage of the 
photoheterotrophic activity to promote growth, expanding the known effects of light upon this globally abundant marine bacterial taxon. Our results further suggest that light may promote the maintenance of cell integrity in a substantial fraction of coastal marine bacteria. If confirmed, light should be regarded not only as an "extra" energy source, but a requirement for some photoheterotrophs to survive in the ocean. 


\section{Experimental procedures}

\section{Study area and sample collection}

Seawater was collected monthly between April and December 2012 at the E2 Gijón/Xixón station in a midshelf area located $37 \mathrm{~km}$ off the coast of Spain $\left(43.675^{\circ} \mathrm{N}, 5.578^{\circ} \mathrm{W}\right)$ in the Southern Bay of Biscay. For convenience, the two samples collected in May, on the $2^{\text {nd }}$ and the $23^{\text {rd }}$, were referred to as “April” and “May”, respectively). Surface water samples were collected at $5 \mathrm{~m}$ depth in $5 \mathrm{~L}$ Niskin bottles and prefiltered through $0.8 \mu \mathrm{m}$ to minimize the presence of predators and phytoplankton cells in the incubations. In addition to seawater collection, CTD (SeaBird 25) profiles were carried out in the water column of the sampling area to measure in situ parameters. Samples were transported to the lab within six hours in 20L polycarbonate bottles (Nalgene). In situ Chl $a$ concentration was determined by filtering $200 \mathrm{ml}$ of seawater on $0.2 \mu \mathrm{m}$ pore-size polycarbonate filters. Filters were frozen at $-20^{\circ} \mathrm{C}$ and processed within two weeks as described by Calvo-Díaz and Morán (2006).

RNA extraction and processing for metatranscriptomic analysis

Seawater samples for RNA extraction were collected in April, May, July and November. Seawater was filtered onto $0.2-\mu \mathrm{m}$ pore-size polycarbonate filtered and freezed in liquid nitrogen until the arrival to the laboratory, where they were stored at $-80^{\circ} \mathrm{C}$. These filters were shattered with a mallet, vortexed in falcon tubes containing Power Soil beads (Mobio), and the lysate was mixed with 70\% ethanol (1:1 volume). The RNA extraction was carried out with the RNeasy Mini Kit (Qiagen). RNA was treated with Turbo DNAse (Ambion) and the ribosomal RNA was depleted using the mRNA-only isolation kit (Epicentre) and the MicrobeExpress and MicrobeEnrich kits (Ambion). The enriched mRNAs were linearly amplified using the Message Amp II-Bacteria kit (Ambion), reverse transcribed to double-stranded complementary DNA 
(cDNA) with the Universal Riboclone cDNA synthesis system (Promega) and purified with the QIAQuick PCR purification kit (Qiagen). The eight cDNA samples were subjected to single-end sequencing by Illumina Miseq technology.

A custom-made database contained the peptides derived from the set of complete and partial genomes from the MAR database (9407 genomes, August 2018). Only the peptides of interest (rhodopsin and TonB receptor families) were annotated based on a search using hidden Markov models (HMM) either already available in the families and superfamilies in the Protein Families Database (Pfam) v. 31.0 or TIGRFAM v. 15.0 databases, or an HMM specifically designed as described in supplementary information 1. BLASTx mapped the metatranscriptome sequence reads to the peptide database. A BLASTx hit was considered valid if the bitscore was equal or greater than 50 .

\section{Experimental design}

A volume of 20 L of seawater was collected at E2 Gijón/Xixón station and filtered through $0.8 \mu \mathrm{m}$ as described above. Once in the lab, three transparent 4-L polycarbonate bottles (Nalgene) were filled with 2 L of the sampling water (“light treatment”). Additionally, three polycarbonate bottles were filled with $2 \mathrm{~L}$ of water and wrapped with aluminum foil and black tape to keep the water under complete dark conditions (“dark treatment”). The bottles were maintained in incubators between 3-5 days (except in the incubation of December, which lasted 7 days) at in situ temperature and under saturating PAR light irradiance of 435 mmol photons $\mathrm{m}^{-2} \mathrm{~s}^{-1}$, conditions mimicking the photoperiod of the sampling day. Every day during the incubations, 2-3 samples were taken to determine microbial and flagellate abundance by flow cytometry, as well as by CARD-FISH analysis. 
To estimate the abundance of Live and Dead microbes, cells with intact and damaged membrane respectively, the nucleic acid double staining (NADS) protocol was used (Gregori et al., 2001). Volumes of $400 \mu \mathrm{L}$ for each replicate were stained with $4 \mu \mathrm{L}$ of Sybr green I (SG1; Molecular Probes, Eugene, OR; $10 \mu \mathrm{g} \mathrm{mL}-1$ ) and $4 \mu \mathrm{L}$ cell-impermeant PI (Sigma Chemical Co.) fluorescent probe $\left(10 \mu \mathrm{g} \mathrm{mL} \mathrm{m}^{-1}\right)$ and incubated in the dark for 15 minutes to quantify Live cells (with intact membranes) and Dead cells (with damaged membranes). Microbial abundance was analyzed with a FACSCalibur flow cytometer (Becton Dickinson) equipped with a blue (488-nm) argon laser.

Heterotrophic nanoflagellate (HNF) abundance was determined on 1\% glutaraldehyde-fixed samples by flow cytometry using a FACSCalibur Flow Cytometer (Becton Dickinson; see details in Christaki et al., 2011) . To determine the abundance of cyanobacteria and picoeukaryotes, $1.8 \mathrm{~mL}$ of water was sampled before and after the pre-filtration treatment. Samples were fixed in 1\% paraformaldehyde and $0.05 \%$ glutaraldehyde (final concentration) and stored at $-80^{\circ} \mathrm{C}$ until the flow-cytometry analysis. Both groups were differentiated using red (FL3) and orange (FL2) fluorescence signals.

\section{Abundance and growth of specific phylogenetic bacterial groups}

To estimate the abundance of different phylogenetic bacterial groups during the incubations, duplicate samples were analyzed by CARD-FISH (Pernthaler et al., 2008). The probes and formamide concentrations used were: SAR11-441R (Morris et al., 2002), 45\% formamide for SAR11 group; Ros537 (Eilers et al., 2000), 55\% formamide for Rhodobacteraceae; Gam42a (Amann et al., 1990) and its competitor Bet42a (Manz et al., 1992), 55\% formamide for Gammaproteobacteria; CF319 (Amann et al., 1990), 55\% formamide for Bacteroidetes; POL740 (Malmstrom et al., 2007), 35\% formamide for Polaribacter; Alt1413 (Eilers et al., 2000), 60\% formamide for Alteromonas; and a probe newly designed in this work, 
Ten135 (5'-aggctatcctcctgtacaag-3') and its competitor Ten135c (5'-aggctatcctcctgtaaaag-3'), 20\% formamide for Tenacibaculum. Hybridized samples were transferred onto slides and stained with 4',6diamidino-2-phenylindole (DAPI) at $1 \mu \mathrm{g} \mathrm{mL} \mathrm{mL}^{-1}$. DAPI and CARD-FISH stained bacteria were quantified with an epifluorescence microscope Leica DM5500B, a monochromatic camera Leica DFC360 FX and the ACMETool2 automatized image analysis software (Zeder et al., 2011).

Growth rates of bacteria were estimated for the entire microbial community, as well as for each phylogenetic group, as the slope between ln-transformed abundance against time during the exponential growth phase. Maximum abundance reached during the stationary growth phase by the bacterial community and each phylogenetic group was also calculated. Statistical differences between the growth rates of each treatment were estimated by covariance analysis (ANCOVA), determining statistical differences in the change of the bacterial abundance with time for each treatment.

\section{DNA extraction and sequencing}

Samples for DNA extraction were collected at the initial time of the incubations and when total microbe abundances reached their maximum, which was determined by daily monitoring of bacterial abundance using flow-cytometry. Samples were pre-filtered through GF/A $47 \mathrm{~mm}$ filters (Whatman) and biomass was collected onto $0.2 \mu \mathrm{m}$ pore-size $47 \mathrm{~mm}$ polycarbonate filters (Millipore) for DNA extraction. Filters were immediately frozen at $-80^{\circ} \mathrm{C}$ for storage before extraction. DNA was extracted using the PowerWater DNA Isolation Kit (Mobio, Carlsbad, USA) according to the manufacturer's instructions.

To determine prokaryotic community composition, DNA was amplified (see details in supplementary information 1) and analyzed by pyrosequencing with a 454 FLX+ system (ROCHE software v2.8). Sequences were analyzed with the Mothur platform (Schloss et al., 2009) as indicated in Alonso-Sáez et 
al. (2015). In addition to amplicon sequencing, clone libraries were analyzed in the spring samples (May and June, in situ and light treatment) to obtain a finer phylogenetic resolution of the taxa growing in the incubations by sequencing the full 16S rRNA gene (see details in supplementary information 1).

Bioinformatic pipeline for TonB receptors and PR analysis

We analyzed the abundance of predicted SusC/SusD and TonB receptor genes, including receptors considered specific for vitamin $\mathrm{B}_{1}$ and for haem groups in a set of complete genomes downloaded from the MAR database (https://mmp.sfb.uit.no/databases/; 798 genomes; August 2018). See supplementary information 1 section for more information. Similarly, the abundance of PR peptides was also identified by the corresponding PFAM (PF01036) in the Protein Families Database (Pfam) v. 32.0. Further description of these analysis is provided as supplementary information 1. 
Conflict of interests: The authors declare that they have no conflict of interests.

Acknowledgments. We are grateful to Basque Government for supporting N.A.G.'s Ph.D. fellowship the Spanish Ministry of Economy and Competitiveness (MINECO) for supporting L.A.S.'s Juan de la Cierva and Ramón y Cajal fellowship (RYC-2012-11404) and the COMITE project (CTM-2010-15840). The Spanish Ministry of Economy and Competitiveness also supported J.M.G project (CTM2016-80095-C2-2R). We are very thankful to all the staff of the R/V "José de Rioja” for their help during the sampling collection and L. Díaz for her help during the experiments. We are also grateful to A. R. Bausch for English editing. 


\section{References}

Alonso-Sáez, L., Díaz-Pérez, L., and Morán, X.A.G. (2015) The hidden seasonality of the rare biosphere in coastal marine bacterioplankton. Environ Microbiol 17: 3766-3780.

Alonso-Sáez, L., Pinhassi, J., Pernthaler, J., and Gasol, J.M. (2010) Leucine-to-carbon empirical conversion factor experiments: does bacterial community structure have an influence? Environ Microbiol 12: 2988-2997.

Alonso-Sáez, L., Gasol, J.M., Lefort, T., Hofer, J., and Sommaruga, R. (2006) Effect of natural sunlight on bacterial activity and differential sensitivity of natural bacterioplankton groups in northwestern Mediterranean coastal waters. Appl Environ Microbiol 72: 5806-5813.

Amann, R.I., Krumholz, L., and Stahl, D.A. (1990) Fluorescent-oligonucleotide probing of whole cells for determinative, phylogenetic, and environmental studies in microbiology. J Bacteriol 172: 762-770.

Arandia-Gorostidi, N., Huete-Stauffer, T.M., Alonso-Sáez, L., and Morán, X.A.G. (2017) Testing the metabolic theory of ecology with marine bacteria: different temperature sensitivity of major phylogenetic groups during the spring phytoplankton bloom. Environ Microbiol.

Béjà, O., Aravind, L., Koonin, E.V., Suzuki, M.T., Hadd, A., Nguyen, L.P. et al. (2000) Bacterial rhodopsin: evidence for a new type of phototrophy in the sea. Science 289: 1902-1906.

Biebl, H., and Wagner-Döbler, I. (2006) Growth and bacteriochlorophyll a formation in taxonomically diverse aerobic anoxygenic phototrophic bacteria in chemostat culture: Influence of light regimen and starvation. Process Biochemistry 41: 2153-2159.

Biller, S.J., Coe, A., Roggensack, S.E., and Chisholm, S.W. (2018) Heterotroph Interactions Alter Prochlorococcus Transcriptome Dynamics during Extended Periods of Darkness. mSystems 3. 
Boeuf, D., Lami, R., Cunnington, E., and Jeanthon, C. (2016) Summer Abundance and Distribution of Proteorhodopsin Genes in the Western Arctic Ocean. Front Microbiol 7: 1584.

Calvo-Díaz, A., and Morán, X.A.G. (2006) Seasonal dynamics of picoplankton in shelf waters of the southern Bay of Biscay. Aquatic Microbial Ecology 42: 159-174.

Calvo-Díaz, A., Morán, X.A.G., and Suárez, L.Á. (2008) Seasonality of picophytoplankton chlorophyll a and biomass in the central Cantabrian Sea, southern Bay of Biscay. Journal of Marine Systems 72: 271-281.

Campbell, B.J., Waidner, L.A., Cottrell, M.T., and Kirchman, D.L. (2008) Abundant proteorhodopsin genes in the North Atlantic Ocean. Environ Microbiol 10: 99-109.

Christaki, U., Courties, C., Massana, R., Catala, P., Lebaron, P., Gasol, J.M., and Zubkov, M.V. (2011) Optimized routine flow cytometric enumeration of heterotrophic flagellates using SYBR Green I. Limnology and Oceanography: Methods 9: 329-339.

de la Torre, J.R., Christianson, L.M., Beja, O., Suzuki, M.T., Karl, D.M., Heidelberg, J., and DeLong, E.F. (2003) Proteorhodopsin genes are distributed among divergent marine bacterial taxa. Proc Natl Acad Sci U S A 100: 12830-12835.

DeLong, E.F., and Béjà, O. (2010) The light-driven proton pump proteorhodopsin enhances bacterial survival during tough times. PLoS Biol 8: e1000359.

Eilers, H., Pernthaler, J., Glockner, F.O., and Amann, R. (2000) Culturability and In situ abundance of pelagic bacteria from the North Sea. Appl Environ Microbiol 66: 3044-3051.

Feng, S., Powell, S.M., Wilson, R., and Bowman, J.P. (2013) Light-stimulated growth of proteorhodopsinbearing sea-ice psychrophile Psychroflexus torquis is salinity dependent. ISME J 7: 2206-2213. 
Fernández-Gómez, B. (2012) Ecology of marine Bacteroidetes: a genomics approach. PhD thesis, Universidad de Las Palmas de Gran Canaria, Spain.

Ferrera, I., Sánchez, O., Kolarova, E., Koblizek, M., and Gasol, J.M. (2017) Light enhances the growth rates of natural populations of aerobic anoxygenic phototrophic bacteria. ISME J 11: 2391-2393.

Finkel, O.M., Béjà, O., and Belkin, S. (2013) Global abundance of microbial rhodopsins. ISME J 7: 448451.

Frigaard, N.U., Martínez, A., Mincer, T.J., and DeLong, E.F. (2006) Proteorhodopsin lateral gene transfer between marine planktonic Bacteria and Archaea. Nature 439: 847-850.

Giovannoni, S.J. (2017) SAR11 Bacteria: The Most Abundant Plankton in the Oceans. Ann Rev Mar Sci 9: 231-255.

Giovannoni, S.J., Bibbs, L., Cho, J.C., Stapels, M.D., Desiderio, R., Vergin, K.L. et al. (2005) Proteorhodopsin in the ubiquitous marine bacterium SAR11. Nature 438: 82-85.

Gómez-Consarnau, L., González, J.M., Riedel, T., Jaenicke, S., Wagner-Dobler, I., Sanudo-Wilhelmy, S.A., and Fuhrman, J.A. (2016) Proteorhodopsin light-enhanced growth linked to vitamin-B1 acquisition in marine Flavobacteria. ISME J 10: 1102-1112.

Gómez-Consarnau, L., González, J.M., Coll-Llado, M., Gourdon, P., Pascher, T., Neutze, R. et al. (2007) Light stimulates growth of proteorhodopsin-containing marine Flavobacteria. Nature 445: 210213.

Gómez-Consarnau, L., Akram, N., Lindell, K., Pedersen, A., Neutze, R., Milton, D.L. et al. (2010) Proteorhodopsin phototrophy promotes survival of marine bacteria during starvation. PLoS Biol 8: e1000358. 
González, J.M., Fernández-Gómez, B., Fernández-Guerra, A., Gómez-Consarnau, L., Sánchez, O., CollLlado, M. et al. (2008) Genome analysis of the proteorhodopsin-containing marine bacterium Polaribacter sp. MED152 (Flavobacteria). Proc Natl Acad Sci U S A 105: 8724-8729.

Gregori, G., Citterio, S., Ghiani, A., Labra, M., Sgorbati, S., Brown, S., and Denis, M. (2001) Resolution of Viable and Membrane-Compromised Bacteria in Freshwater and Marine Waters Based on Analytical Flow Cytometry and Nucleic Acid Double Staining. Applied and Environmental Microbiology 67: 4662-4670.

Huete-Stauffer, T.M., Arandia-Gorostidi, N., Díaz-Pérez, L., and Morán, X.A.G. (2015) Temperature dependences of growth rates and carrying capacities of marine bacteria depart from metabolic theoretical predictions. FEMS Microbiol Ecol 91.

Jacquet, S., Partensky, F., Lennon, J.F., and Vaulot, D. (2001) Diel patterns of growth and division in marine picoplankton in culture. Journal of Phycology 37: 357-369.

Kirchman, D.L. (2016) Growth Rates of Microbes in the Oceans. Ann Rev Mar Sci 8: 285-309.

Klemetsen, T., Raknes, I.A., Fu, J., Agafonov, A., Balasundaram, S.V., Tartari, G. et al. (2018) The MAR databases: development and implementation of databases specific for marine metagenomics. Nucleic Acids Res 46: D692-D699.

Klindworth, A., Mann, A.J., Huang, S., Wichels, A., Quast, C., Waldmann, J. et al. (2014) Diversity and activity of marine bacterioplankton during a diatom bloom in the North Sea assessed by total RNA and pyrotag sequencing. Mar Genomics 18 Pt B: 185-192.

Kopel, M., Helbert, W., Henrissat, B., Doniger, T., and Banin, E. (2014) Draft Genome Sequences of Two Ulvan-Degrading Isolates, Strains LTR and LOR, That Belong to the Alteromonas Genus. Genome Announc 2. 
Lemée, R., Rochelle-Newall, E., Van Wambeke, F., Pizay, M.D., Rinaldi, P., and Gattuso, J.P. (2002) Seasonal variation of bacterial production, respiration and growth efficiency in the open NW Mediterranean Sea. Aquatic Microbial Ecology 29: 227-237.

Malmstrom, R.R., Straza, T.R.A., Cottrell, M.T., and Kirchman, D.L. (2007) Diversity, abundance, and biomass production of bacterial groups in the western Arctic Ocean. Aquatic Microbial Ecology 47: 45-55.

Manz, W., Amann, R., Ludwig, W., Wagner, M., and Schleifer, K.-H. (1992) Phylogenetic Oligodeoxynucleotide Probes for the Major Subclasses of Proteobacteria: Problems and Solutions. Systematic and Applied Microbiology 15: 593-600.

Martínez, A., Bradley, A.S., Waldbauer, J.R., Summons, R.E., and DeLong, E.F. (2007) Proteorhodopsin photosystem gene expression enables photophosphorylation in a heterologous host. Proc Natl Acad Sci U S A 104: 5590-5595.

Mella-Flores, D., Six, C., Ratin, M., Partensky, F., Boutte, C., Le Corguille, G. et al. (2012) Prochlorococcus and Synechococcus have Evolved Different Adaptive Mechanisms to Cope with Light and UV Stress. Front Microbiol 3: 285.

Michelou, V.K., Cottrell, M.T., and Kirchman, D.L. (2007) Light-stimulated bacterial production and amino acid assimilation by cyanobacteria and other microbes in the North Atlantic ocean. Appl Environ Microbiol 73: 5539-5546.

Moran, M.A., and Miller, W.L. (2007) Resourceful heterotrophs make the most of light in the coastal ocean. Nat Rev Microbiol 5: 792-800.

Morán, X.A.G., and Calvo-Díaz, A. (2009) Single-cell vs. bulk activity properties of coastal bacterioplankton over an annual cycle in a temperate ecosystem. FEMS Microbiol Ecol 67: 43-56. 
Morán, X.A.G., Massana, R., and Gasol, J.M. (2001) Light conditions affect the measurement of oceanic bacterial production via leucine uptake. Appl Environ Microbiol 67: 3795-3801.

Morris, R.M., Rappé, M.S., Connon, S.A., Vergin, K.L., Siebold, W.A., Carlson, C.A., and Giovannoni, S.J. (2002) SAR11 clade dominates ocean surface bacterioplankton communities. Nature 420: 806810.

Olson, D.K., Yoshizawa, S., Boeuf, D., Iwasaki, W., and DeLong, E.F. (2018) Proteorhodopsin variability and distribution in the North Pacific Subtropical Gyre. ISME J 12: 1047-1060.

Pearman, J.K., Casas, L., Merle, T., Michell, C., and Irigoien, X. (2016) Bacterial and protist community changes during a phytoplankton bloom. Limnology and Oceanography 61: 198-213.

Pernthaler, A., Pernthaler, J., and Amann, R. (2008) Section 3 update: Sensitive multi-color fluorescence in situ hybridization for the identification of environmental microorganisms. 2613-2627.

Qin, Q.L., Xie, B.B., Shu, Y.L., Rong, J.C., Zhao, D.L., Zhang, X.Y. et al. (2012) Genome sequence of proteorhodopsin-containing sea ice bacterium Glaciecola punicea ACAM 611T. J Bacteriol 194: 3267.

Ruiz-González, C., Lefort, T., Gali, M., Montserrat Sala, M., Sommaruga, R., Simo, R., and Gasol, J.M. (2012) Seasonal patterns in the sunlight sensitivity of bacterioplankton from Mediterranean surface coastal waters. FEMS Microbiol Ecol 79: 661-674.

Rusch, D.B., Halpern, A.L., Sutton, G., Heidelberg, K.B., Williamson, S., Yooseph, S. et al. (2007) The Sorcerer II Global Ocean Sampling expedition: northwest Atlantic through eastern tropical Pacific. PLoS Biol 5: e77. 
Salazar, G., Cornejo-Castillo, F.M., Benitez-Barrios, V., Fraile-Nuez, E., álvarez-Salgado, X.A., Duarte, C.M. et al. (2016) Global diversity and biogeography of deep-sea pelagic prokaryotes. ISME J 10: 596-608.

Schloss, P.D., Westcott, S.L., Ryabin, T., Hall, J.R., Hartmann, M., Hollister, E.B. et al. (2009) Introducing mothur: open-source, platform-independent, community-supported software for describing and comparing microbial communities. Appl Environ Microbiol 75: 7537-7541.

Schwalbach, M.S., and Fuhrman, J.A. (2005) Wide-ranging abundances of aerobic anoxygenic phototrophic bacteria in the world ocean revealed by epifluorescence microscopy and quantitative PCR. Limnology and Oceanography 50: 620-628.

Schwalbach, M.S., Brown, M., and Fuhrman, J.A. (2005) Impact of light on marine bacterioplankton community structure. Aquatic Microbial Ecology 39: 235-245.

Sharma, A.K., Spudich, J.L., and Doolittle, W.F. (2006) Microbial rhodopsins: functional versatility and genetic mobility. Trends Microbiol 14: 463-469.

Sommaruga, R., Hofer, J.S., Alonso-Sáez, L., and Gasol, J.M. (2005) Differential sunlight sensitivity of picophytoplankton from surface Mediterranean Coastal Waters. Appl Environ Microbiol 71: 21542157.

Steindler, L., Schwalbach, M.S., Smith, D.P., Chan, F., and Giovannoni, S.J. (2011) Energy starved Candidatus Pelagibacter ubique substitutes light-mediated ATP production for endogenous carbon respiration. PLoS One 6: e19725.

Stingl, U., Desiderio, R.A., Cho, J.C., Vergin, K.L., and Giovannoni, S.J. (2007) The SAR92 clade: an abundant coastal clade of culturable marine bacteria possessing proteorhodopsin. Appl Environ Microbiol 73: 2290-2296. 
Tada, Y., Taniguchi, A., Nagao, I., Miki, T., Uematsu, M., Tsuda, A., and Hamasaki, K. (2011) Differing growth responses of major phylogenetic groups of marine bacteria to natural phytoplankton blooms in the western North Pacific Ocean. Appl Environ Microbiol 77: 4055-4065.

Tang, K., Jiao, N., Liu, K., Zhang, Y., and Li, S. (2012) Distribution and functions of TonB-dependent transporters in marine bacteria and environments: implications for dissolved organic matter utilization. PLoS One 7: e41204.

Shiba, T., Simidu, U., and Taga, N. (1979) Distribution of Aerobic Bacteria Which Contain Bacteriochlorophyll a. Applied and Environmental Microbiology 38: 3.

Tully, B.J., Sachdeva, R., Graham, E.D., and Heidelberg, J.F. (2017) 290 metagenome-assembled genomes from the Mediterranean Sea: a resource for marine microbiology. PeerJ 5: e3558.

V. K. Michelou, M.S.R. (2014) The effect of light on the physiology of HIMB30, a proteorhodopsincontaining marine gammaproteobacterium possessing the genetic machinery for carbon fixation. In ASLO Ocean Sciences Meeting. Honolulu, Hawaii, USA.

Vaulot, D., Marie, D., Olson, R.J., and Chisholm, S.W. (1995) Growth of prochlorococcus, a photosynthetic prokaryote, in the equatorial pacific ocean. Science 268: 1480-1482.

Venter, J.C., Remington, K., Heidelberg, J.F., Halpern, A.L., Rusch, D., Eisen, J.A. et al. (2004) Environmental genome shotgun sequencing of the Sargasso Sea. Science 304: 66-74.

Xing, P., Hahnke, R.L., Unfried, F., Markert, S., Huang, S., Barbeyron, T. et al. (2015) Niches of two polysaccharide-degrading Polaribacter isolates from the North Sea during a spring diatom bloom. ISME J 9: 1410-1422. 
Yoshizawa, S., Kawanabe, A., Ito, H., Kandori, H., and Kogure, K. (2012) Diversity and functional analysis of proteorhodopsin in marine Flavobacteria. Environ Microbiol 14: 1240-1248.

Yoshizawa, S., Kumagai, Y., Kim, H., Ogura, Y., Hayashi, T., Iwasaki, W. et al. (2014) Functional characterization of flavobacteria rhodopsins reveals a unique class of light-driven chloride pump in bacteria. Proc Natl Acad Sci U S A 111: 6732-6737.

Yurkov, V.V., and van Gemerden, H. (1993) Impact of light/dark regimen on growth rate, biomass formation and bacteriochlorophyll synthesis in Erythromicrobium hydrolyticum. Archives of Microbiology 159: 84-89.

Zeder, M., Ellrott, A., and Amann, R. (2011) Automated sample area definition for high-throughput microscopy. Cytometry A 79: 306-310. 


\section{Table legends}

Table 1 In situ values for temperature and pre-filtration and post-filtration abundances of heterotrophic bacteria, heterotrophic nanoflagellates (HNF), cyanobacteria (Synechococcus + Prochlorococcus) and autotrophic picoeukaryotes and chlorophyll a concentration. "n.d.” indicates that no abundance was detected and NA that data is not available. 


\section{Figure legends}

Figure 1 (A) Percent of PR transcripts relative to all detected transcripts found at the in situ conditions of April, May, July and November. (B) Relative contribution of different prokaryotic taxa to the PR transcript pool.

Figure 2 (A) Percentage of cytometric group Live bacteria in light (orange) and dark (black) treatments and (B) total bacterial community growth rates for the entire bacterial community. Error bars represent SD between three replicates.

Figure 3 (A) Relative abundance of top 20 bacterial OTUs at in situ conditions as analyzed by amplicon sequencing between April and December 2012. B) Multidimensional (MDS) plot of bacterial community composition obtained by amplicon sequencing for the incubations of June, July, August and December at the beginning of the incubation (T0) and the end of the light and dark treatments.

Figure 4 (A) Bacterial growth rates for each phylogenetic group (SAR11, Rhodobacteraceae, Gammaproteobacteria and Bacteroidetes) and each monthly experiment. (B) Growth curves for Polaribacter, Tenacibaculum (Bacteroidetes), Alteromonadales (Gammaproteobacteria) and SAR11 (Alphaproteobacteria) groups in the incubation of May in light (orange line) and dark (black line) treatments. Error bars represent SD between two replicates.

Figure 5 (A) Percent of reads that target genes that encode haem and vitamin $B_{1}$ transporters (left y-axis) and TonB (in susC-susD tandem) transporter (right y-axis) relative to all TonB receptor transcripts found in the metatranscriptomes. (B) Number of predicted TonB transporter receptors for each bacterial genus found in a set of complete genomes downloaded from the MAR database. Different color boxes indicate 
taxonomical affiliation. Green, blue and yellow stars specify presence of SusC/SusD, specific vitamin $\mathrm{B}_{1}$ and haem TonB receptor genes in at least one of the genomes of each genus. 

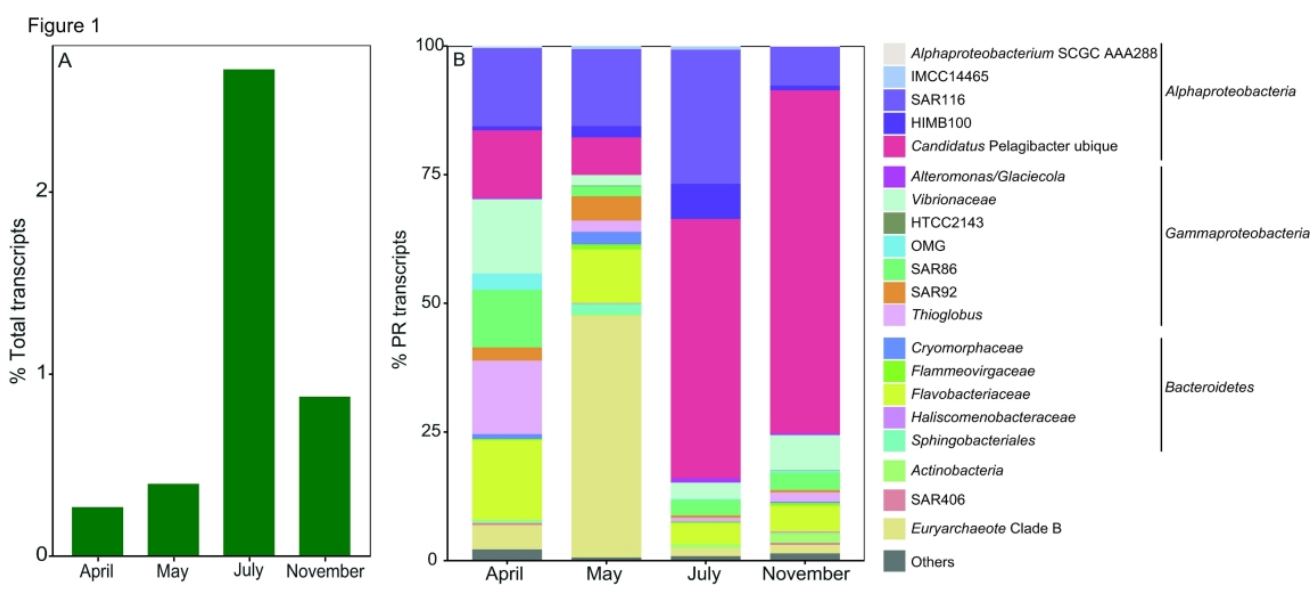

Figure 1 (A) Percent of PR transcripts relative to all detected transcripts found at the in situ conditions of April, May, July and November. (B) Relative contribution of different prokaryotic taxa to the PR transcript pool.

$319 \times 140 \mathrm{~mm}(300 \times 300 \mathrm{DPI})$ 
Figure 2
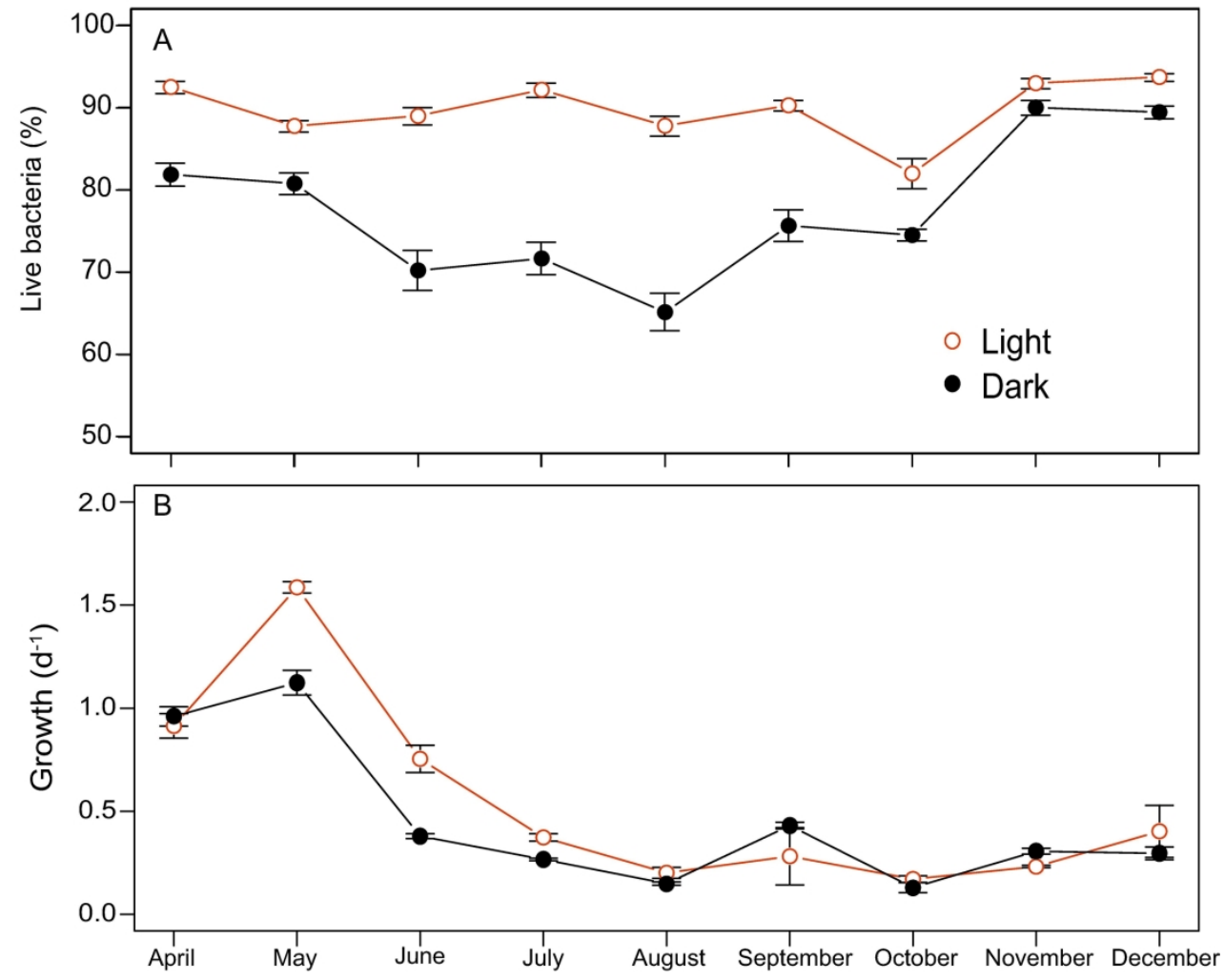

Figure 2 (A) Percentage of cytometric group Live bacteria in light (orange) and dark (black) treatments and (B) total bacterial community growth rates for the entire bacterial community. Error bars represent SD between three replicates.

$205 \times 168 \mathrm{~mm}(300 \times 300 \mathrm{DPI})$ 
Figure 4

A
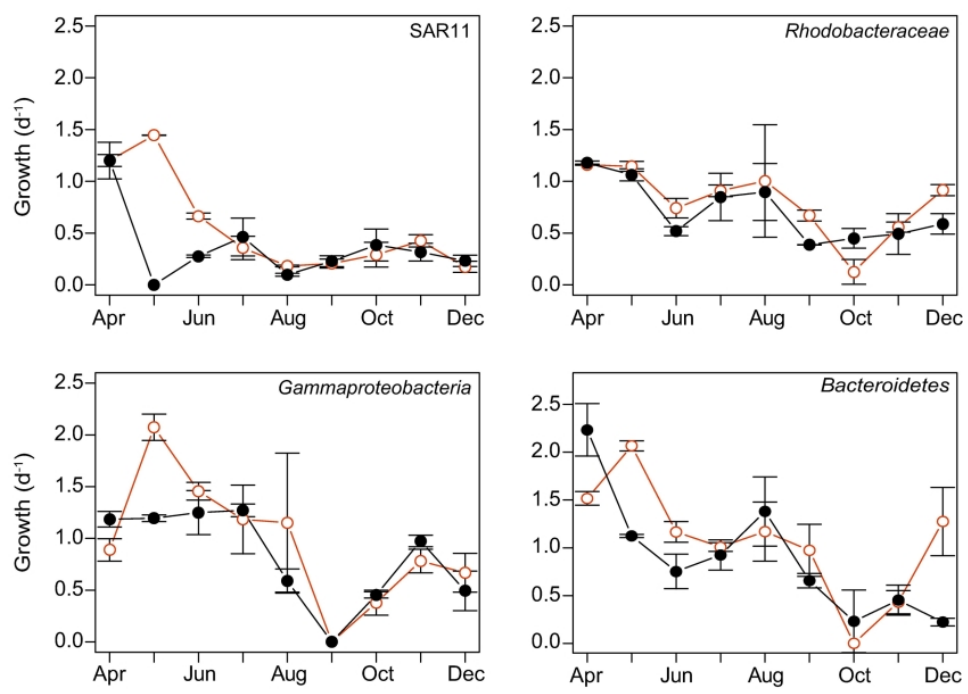

B
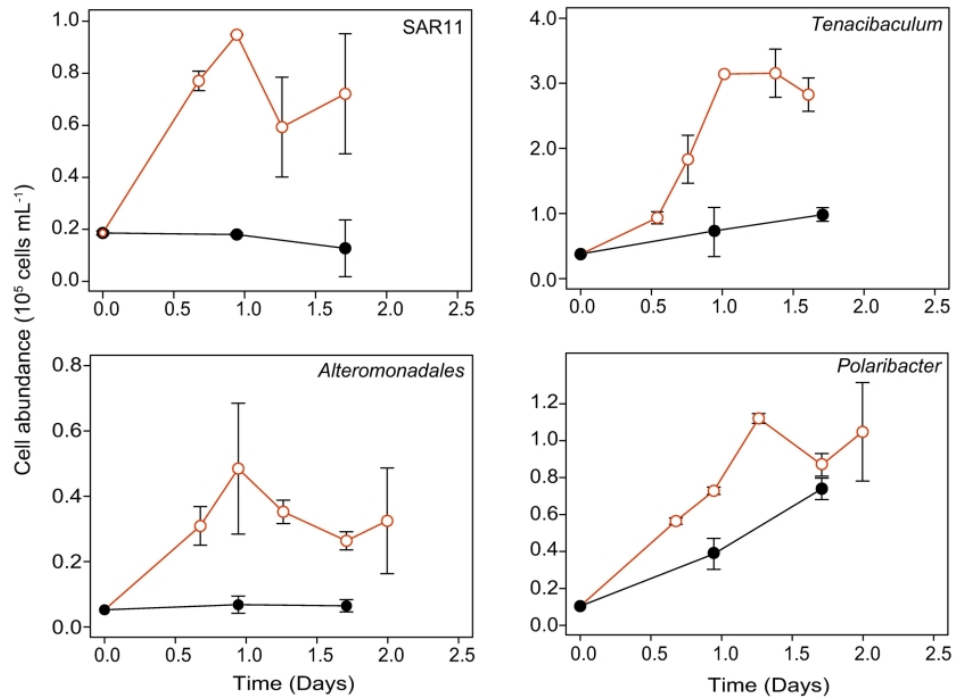

Figure 4 (A) Bacterial growth rates for each phylogenetic group (SAR11, Rhodobacteraceae, Gammaproteobacteria and Bacteroidetes) and each monthly experiment. (B) Growth curves for Polaribacter, Tenacibaculum (Bacteroidetes), Alteromonadales (Gammaproteobacteria) and SAR11 (Alphaproteobacteria) groups in the incubation of May in light (orange line) and dark (black line) treatments. Error bars represent SD between two replicates.

$226 \times 339 \mathrm{~mm}(300 \times 300 \mathrm{DPI})$

This article is protected by copyright. All rights reserved. 

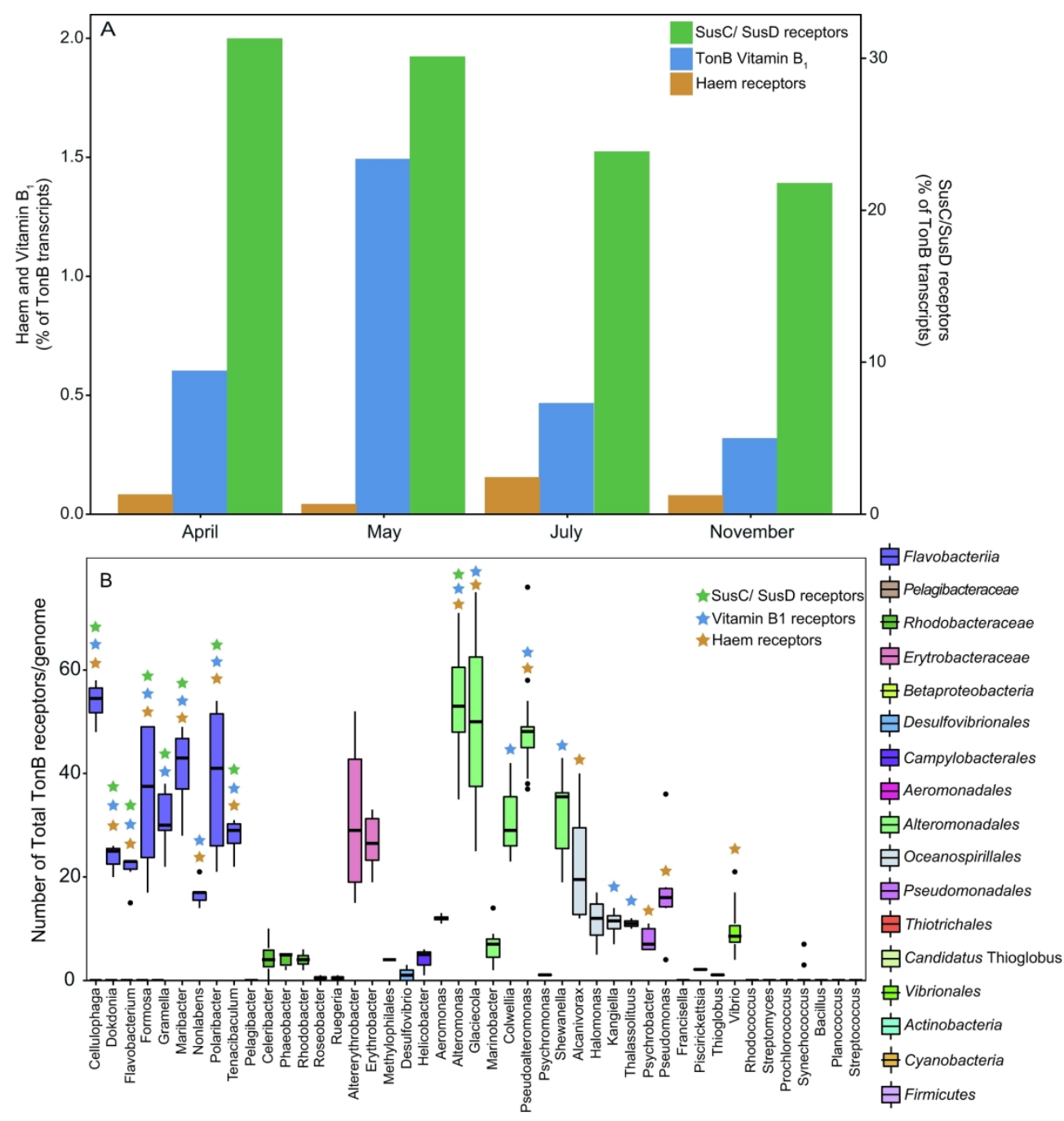

Figure 5 (A) Percent of reads that target genes that encode haem and vitamin B1 transporters (left $y$-axis) and TonB (in susC-susD tandem) transporter (right y-axis) relative to all TonB receptor transcripts found in the metatranscriptomes. (B) Number of predicted TonB transporter receptors for each bacterial genus found in a set of complete genomes downloaded from the MAR database. Different color boxes indicate taxonomical affiliation. Green, blue and yellow stars specify presence of SusC/SusD, specific vitamin B1 and haem TonB receptor genes in at least one of the genomes of each genus.

$266 \times 275 \mathrm{~mm}(300 \times 300 \mathrm{DPI})$ 
Table 1

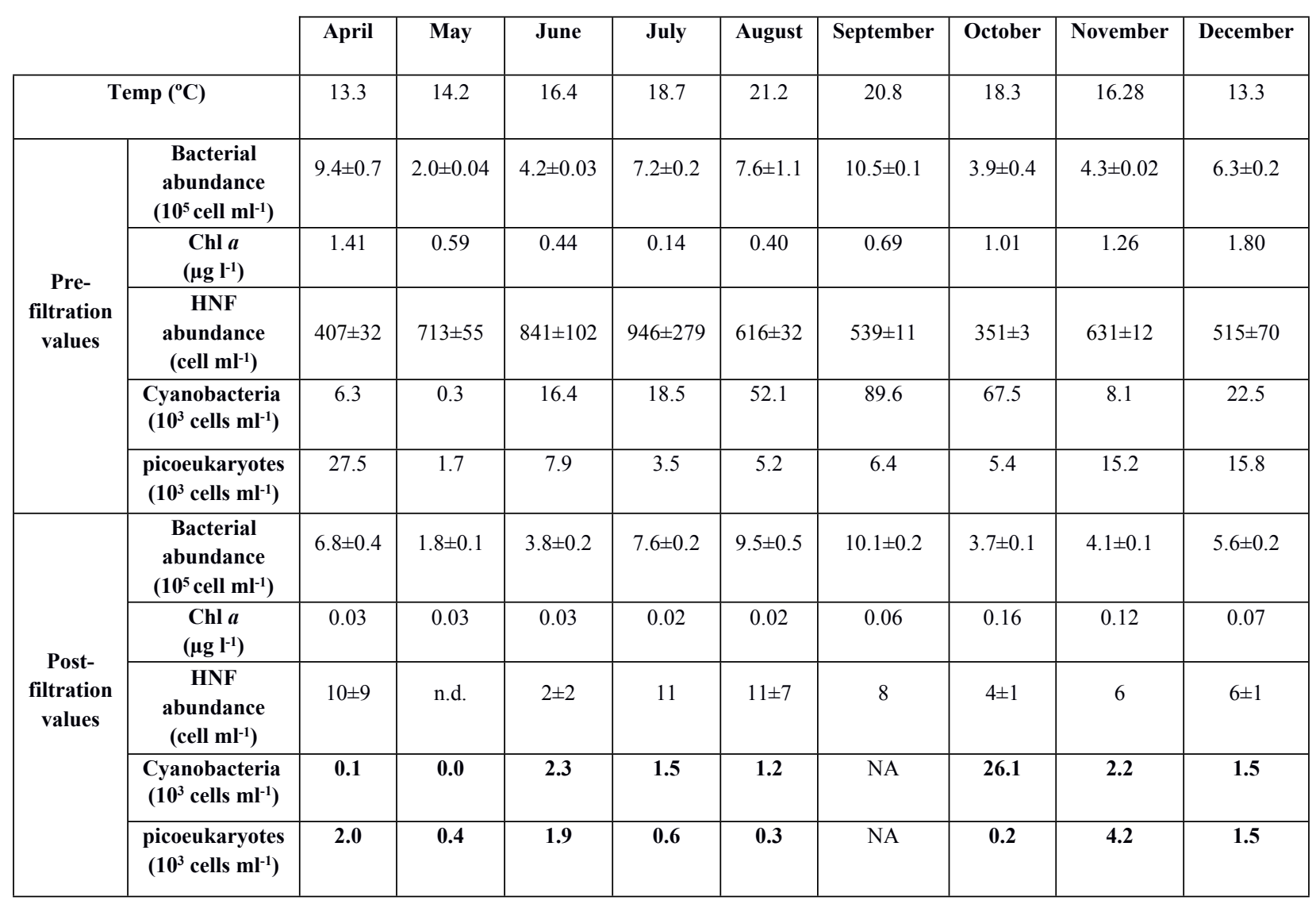

This article is protected by copyright. All rights reserved. 